\title{
Community based sewage treatment through hybrid constructed wetlands system for improved heath \& hygiene and for enhanced agriculture productivity $I$ livelihood generation in rural water scarce environments- Pakistan
}

\author{
Col Islam-ul-Haque ${ }^{1, ~ *}$, Asim Saleem² \\ ${ }^{1}$ Chairman Eco-Logical Sustainability Through Environment Protection Services, Inc, (Eco-STEPS), Islamabad, Pakistan \\ ${ }^{2}$ Country WASH advisor, Plan International Pakistan, Islamabad, Pakistan
}

\section{Email address}

islamhaq3@yahoo.com (C. Islam-ul-Haque)

\section{To cite this article:}

Col Islam-ul-Haque, Asim Saleem. Community Based Sewage Treatment through Hybrid Constructed Wetlands System for Improved Heath \& Hygiene and for Enhanced Agriculture Productivity / Livelihood Generation in Rural Water Scarce Environments-Pakistan. American Journal of Environmental Protection. Vol. 4, No. 1, 2015, pp. 45-54. doi: 10.11648/j.ajep.20150401.17

\begin{abstract}
World over, fresh water scarcity problems are growing in scope \& complexity to multiple factors, like population growth, climatic impacts, excessive water uses pattern in agriculture. A substantial quantum of treated wastewater, can be made available through constructed wetlands, which can supplement the fresh water scarcity. Almost, $80 \%$ of the total generated raw sewage is being discharged into water bodies or being used for agriculture purposes, specially for vegetable farming, which contributes towards fresh water sources and food chain contamination. Centralized mechanical types of wastewater treatment plants are in use which is capital and recurring costs intensive. Resultantly, due to lack of sufficient recurring finances and energy shortages, these sewage treatment plants become non-operational and un-manageable. Moreover, huge centralized sewage treatment plants are difficult to manage due to longer chain of wastewater collection system and inflexibility of reuse of treated water in the areas of its generation. Therefore, keeping in view these obvious impediments, it was envisaged to plan \& implement community based constructed wetlands system for sewage treatment, based on bio and phyto-remediation processes at village Chattal, district Chakwal (an arid area) which is functioning well and being sustained from selling the treated water to farmers and harvesting the various aquatic plants. Temporal analysis was carried out for verification of treatment system efficiency, whereby, monthly wastewater samples were collected at Inlet point (treated water reservoir) and got analyzed for Chemical Oxygen Demand (COD) and Biological Oxygen Demand (BOD) from PCRWR-Islamabad. Analysis report showed significant reduction of COD \& BOD i.e. $86.1 \%$ \& 91.4\% respectively which are under permissible limits of Pak-EPA. Aesthetic value of treated water is remarkably improved after treatment as turbidity reduced from 15 NTU to 2 NTU. Detailed Health survey was carried out at village Chattal, to ascertain, the intervention efficiency. The result showed significant reduction in diarrheal \& Hepatitis diseases i.e. $92.5 \%$ \& $40 \%$ respectively and substantial improvements was observed in socio-economic, biodiversity and health \& environment conditions of the rural population of village Chattal. Pakistan- the study area. This model will prove to be equally good in the rural environments of developing countries, especially in South Asia and Africa.
\end{abstract}

Keywords: Constructed Wetlands, Contamination, Community Based, Capital Cost, Investment, Reuse, Wastewater, Sewage Treatment

\section{Introduction}

\subsection{Background}

The population of world is increasing by alarming rate, mostly in urban center of Asia. The United Nations center for human settlements specifies that the urban population in the Asia and pacific region between 1991 and 2020 is expected to increase from 991 million to 2.44 billion. This means an additional 1.4 billion people will be living in urban centers of 
Asian cities. This quantum increase in population will undermine the provisioning of basic services, like water and sanitation to the people. The increasing rate of rural population to urban migration is the main cause of population growth in urban areas. The year wise water availability in Pakistan is shown in figure-1, below;

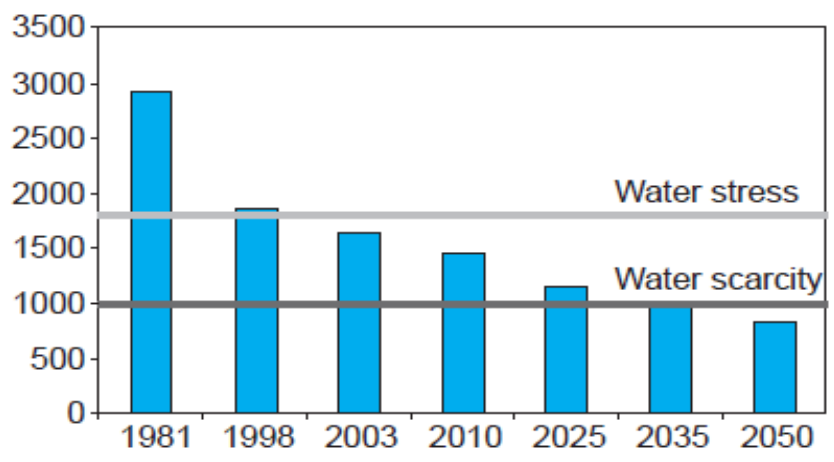

Figure 1. The yearwise water availability in Pakistan

Source: John Brisco \& Usman Qammar (2005), World Bank \& Oxford University

In Pakistan, to meet this demand of increased urban population, mushroom growth of housing societies have been noticed which are unable to fulfill the basic services of water and sanitation. The wastewater from these localities is directly being discharged into natural water bodies like lakes, streams and rivers which is causing massive ground and surface water contamination. The same scenarios are also in place rural areas where wastewater is normally collected in a pond, located in the center of the village, thus causing health $\&$ hygiene problems. Despite drafting national strategy for sustainable environment, provision of safe drinking water and sanitation, the country is still confronted with major challenges in providing sufficient access to drinking water and sanitation, particularly establishing wastewater treatment system. Some of the public health indicators, due to mismanagement of wastewater, in Pakistan are as under;

\subsection{Water Quality and Health Statistics - Pakistan}

The overall water quality and health indicators in Pakistan are appended below;

- $87 \%$ of water in Pakistan is unsafe for human consumption (PCRWR, 2007)

- More than 1.6 million DALYs (Disability Adjusted Life Years) are lost annually as a result of death and disease due to diarrhea, and almost 900,000 as a result of typhoid (World Bank report 2006)

- The total health cost are estimated at Rs. 428 billion, or approximately 5.81 percent of GDP (Pakistan Economic Survey 2011-12)

- Alarmingly, over 2 million people are drinking unsafe water, some with high arsenic concentrations (WWF Report, 2007)

- An estimated over 250,000 child deaths occur each year in Pakistan due to water borne diseases (USAID Report).
The water quality situation both at source and at consumer's end in the project area, district (Chakwal) (PCRWR - report on technical assessment of water supply scheme, 2011); is given in figure-2, below;

\begin{tabular}{|c|c|c|c|c|c|c|c|c|c|}
\hline \multirow[t]{2}{*}{ Tehsil } & \multirow{2}{*}{\multicolumn{2}{|c|}{$\begin{array}{c}\text { Functional } \\
\text { Water Supply } \\
\text { Schemes }\end{array}$}} & \multirow{2}{*}{\multicolumn{2}{|c|}{$\begin{array}{r}\text { Samples } \\
\text { Collected }\end{array}$}} & \multicolumn{2}{|c|}{$\begin{array}{l}\text { Safe for } \\
\text { Drinking }\end{array}$} & \multicolumn{2}{|c|}{$\begin{array}{c}\text { Unsafe } \\
\text { for } \\
\text { Drinking }\end{array}$} & \multirow[t]{2}{*}{ Major Causes of Contamination } \\
\hline & & & & & No & $\%$ & No & $\%$ & \\
\hline Chakwal & \multirow{2}{*}{\multicolumn{2}{|c|}{$\frac{50}{36}$}} & \multicolumn{2}{|c|}{56} & 4 & 7 & 52 & 93 & biological, turbidity, sodium \\
\hline Talagang & & 36 & \multicolumn{2}{|c|}{41} & 14 & 34 & 27 & 66 & biological, nitrate, sodium, turbidity, iron \\
\hline $\begin{array}{l}\text { Choa Saiden } \\
\text { Shah }\end{array}$ & \multicolumn{2}{|l|}{22} & \multicolumn{2}{|c|}{24} & 3 & 13 & 21 & 88 & biological, turbidity, fluoride, hardness \\
\hline Kaller Kahar & \multicolumn{2}{|l|}{18} & \multicolumn{2}{|c|}{19} & - & - & 19 & 100 & biological, turbidity, fluoride \\
\hline District Total & 126 & & 140 & & 21 & 15 & 119 & 85 & \\
\hline \multicolumn{10}{|c|}{ Quality of Water at Consumer's end in District Chakwal } \\
\hline \multirow[t]{2}{*}{ Tehsil } & \multirow{2}{*}{\begin{tabular}{c|} 
Functional \\
Water \\
Supply \\
Schemes \\
\end{tabular}} & \multirow{2}{*}{\multicolumn{2}{|c|}{$\begin{array}{l}\text { Samples } \\
\text { Collected }\end{array}$}} & \multicolumn{2}{|c|}{$\begin{array}{l}\text { Safe for } \\
\text { Drinking }\end{array}$} & \multicolumn{2}{|c|}{$\begin{array}{l}\text { Unsafe for } \\
\text { Drinking }\end{array}$} & \multirow{2}{*}{\multicolumn{2}{|c|}{ Major Causes of Contamination }} \\
\hline & & & & No & $\%$ & No & $\%$ & & \\
\hline Chakwal & 50 & 100 & & 9 & 9 & 91 & 91 & biolog & ical, turbidity, sodium, nitrate, chloride, TDS \\
\hline Talagang & 36 & 72 & & 12 & 17 & 60 & 83 & biolog & ical, nitrate, sodium, turbidity, sulfate, TDS \\
\hline $\begin{array}{l}\text { Choa Saiden } \\
\text { Shah }\end{array}$ & 22 & 44 & & 7 & 16 & 37 & 84 & biolog & ical, turbidity, TDS, nitrate, sodium \\
\hline Kaller Kahar & 18 & 30 & & $\cdot$ & - & 30 & 100 & biolog & ical, turbidity, fluoride \\
\hline District Total & 126 & 246 & & 28 & 11 & 218 & 89 & & \\
\hline
\end{tabular}

Figure 2. Water quality at source and at consumer's end district Chakwal

Hence, keeping in mind the adverse impacts of un-treated wastewater and over all fresh water scarcity situations in Pakistan, Hybrid constructed wetlands sewage treatment, embedded with value addition interventions, a sustainable , cost-effective and environment friendly pilot project was planed and implemented in village Chattal, district Chakwal Pakistan . The salient project objectives are as under;

\section{Project Objectives}

- To protect fresh / drinking water sources from contamination, being caused by un-managed wastewaters in rural environments.

- To create improved health and hygiene environments by reducing mortality and morbidity rates.

- To increase the water resources potentials for irrigation by recycling the treated domestic wastewater through hybrid constructed wetlands system.

- To enhance food security and income generation opportunities at local / village and community levels, specially to marginalized communities / families.

- To create awareness and advocacy among the community for adaptation of improved health and hygiene practices and replication of this model elsewhere.

\section{Study Area Overview}

\subsection{Geographical Location of the Project}

Chattal is located in Chakwal district of the Punjab province of Pakistan which is in the south-east of federal capital Islamabad at a distance of $90 \mathrm{~km}$ and village Chattal is $12 \mathrm{~km}$ from Chakwal city headquarters and can be accessed from both GT road and Motorway -M-2. The aerial view of village Chattal is shown in figure-3, below; 


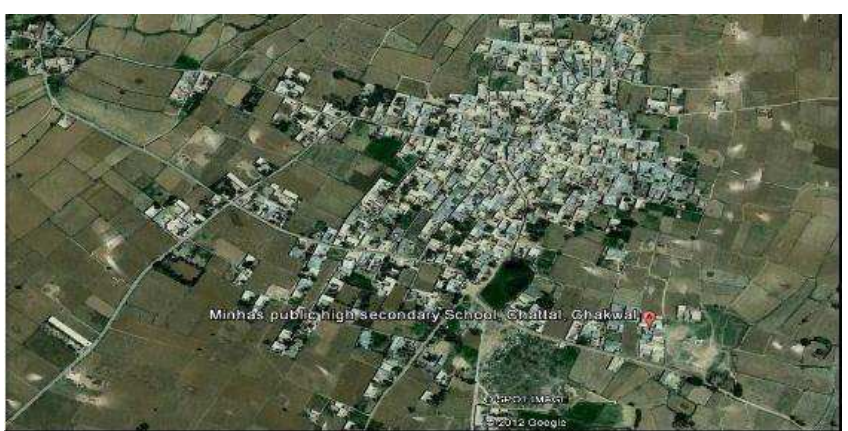

Figure 3. Aerial View of Village Chattal

\subsection{Pre-Project Condition and Need Assessment}

Village Chattal comprises 400 households with approximately a population of 2400 nos. There was no proper mechanism for waste water collection and disposal. 120000 US Gallons/Day (approximately) was being discharged through open drains into an open pond, located within the village premises. The stagnant waste water pond was a big nuisance to local residents and was causing drinking water contamination. The villagers were suffering from water borne diseases due to ground water contamination, the only drinking water source in the area.

The location of existing wastewater ponds, located near water supply scheme is shown in figure-3, below;

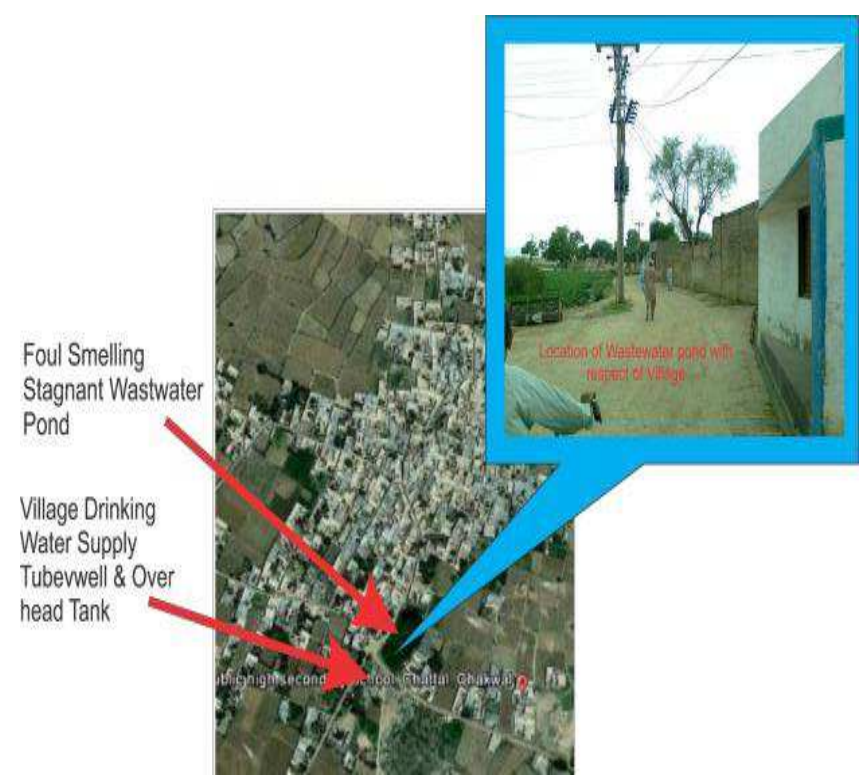

Figure 4. Location of existing foul smelling wastewater collection pond larrangements-Village Chattal-district Chakwal, Pakistan

\section{Literature Review}

In Nepal, low-cost, technology processes were introduced, by which wetlands are constructed and wastewater treated in them. (Krishna Lal Shrestha, 2008). The Environmental Public Health Organisation (ENPHO) introduced constructed wetlands system in Dulikhel (Nepal) Hospital in 1997. Since then this has been followed by 13 such systems at various institutions (e.g. hospitals, schools, university, and monastery) and individual households. The system is found to be highly effective in removing pollutants such as suspended particles, ammonia-nitrogen, BOD, COD and pathogens (Bhushan Tuladhar et al). Organic contaminants removal efficiency is high in all types of constructed wetlands. Domestic sewage normally contains organic matters and, therefore, constructed wetlands technology for sewage treatment is appropriate. (Jan Vymazal, 2010)

\section{Method and Material}

Plan international Pakistan, an International nongovernmental organization working on child health care \& well being, funded this pilot project as a role model for government to ensure sustainable low cost sanitation solutions with reuse of treated wastewater for irrigation \& livelihood generation. Primary objective of this project was to establish model solution at village level, based on low cost technology, sustainable and easy for replication. Therefore a decentralized wastewater treatment system was needed to provide improved health and hygiene environments. The following methodology was adopted/chalked out;

\subsection{Community Mobilization}

Community development facilitator from Plan International Pakistan, carried out community mobilization and their participation for the project ownership to ensure post project sustainability. The district local government representatives were also engaged for requisite government buying.

\subsection{Hybrid Constructed Wetlands Project Design}

Following two major project components are as under;

\subsubsection{Wastewater Collection through Covered Surface Drains}

Plan International Pakistan engaged National Rural Support Program (NRSP) for technical support to community for development of drainage system in village for which community also provided financial contribution, while major funding for construction of covered drains was made available by NRSP through their own sources. The construction of drains was managed/ monitored by the community.

\subsubsection{Hybrid Constructed Wetlands}

Community based Hybrid constructed wetlands system, embedded with value addition interventions was designed due to poor socio-economic conditions of the people. The harvesting of aquatic plants, fish breeding and selling of treated water will generate enough finances to maintain the facility and sufficient livelihood for the work force. Being the newly adopted natural bio-technology in Pakistan, the construction provides for an applied science perspective on this "low cost" wastewater treatment process which uses a combination of aerobic and anaerobic natural treatment systems when combined, called hybrid wetland 
48Col Islam-ul-Haque and Asim Saleem: Community Based Sewage Treatment through Hybrid Constructed Wetlands System for Improved Heath \& Hygiene and for Enhanced Agriculture Productivity / Livelihood Generation in Rural Water Scarce Environments-Pakistan

bioremediation and phyto-remediation waste water treatment technology. The application of this technology demonstrates a sanitation system which protects natural resources, promotes bio-diversity and sustainability. The salient features of the project shown in table-1, below;

Table 1. Project overview, showing various about planning and implementation methodologies

\begin{tabular}{|c|c|}
\hline Type of Project & Small Scale, rural development, low cost sanitation development demonstration \\
\hline Project Completion Period & Start of project: July 2011 \\
\hline Design Value & 400 households, population 2400 discharge 38400 gallons /day \\
\hline Capital Cost & Rs. 3.3 Million or US $32000 \$$ \\
\hline $\begin{array}{l}\text { Planning, Designing, Construction, Execution and } \\
\text { Development }\end{array}$ & NBS and Eco-STEPS Inc (Team Members) \\
\hline Funding Agency & Plan International, Pakistan \\
\hline & $\begin{array}{l}\text {-Village Committee manage the site, as there is no electric \& mechanical appliances and the } \\
\text { entire in-fluent \& effluent flow design is based on gravity flow regime. }\end{array}$ \\
\hline O\&M Cost & $\begin{array}{l}\text {-Gravity flow based system assures the project sustainability and makes O\&M easy. } \\
\text { - Only minimal aquatic plants maintenance will be required, for which finances will be } \\
\text { mustered from value addition interventions }\end{array}$ \\
\hline
\end{tabular}

\subsubsection{Technical Description of the Project}

Bioremediation is a naturally occurring phenomenon in which different plant species accumulate heavy metals, inorganic, toxic and hazardous substances from water and soil and reclaim the water for reuse. Similarly there are many kinds of microbial strains including aerobic and anaerobic, which degrade the organic pollutants into non-toxic smaller fractions. These microbes also accumulate certain heavy metals including chromium, mercury, lead, zinc etc. certain microbes produce such extra cellular enzymes which chelates the heavy metals and due to sedimentation of chelates the wastewater become safe for irrigation. This entire phenomenon is known as biodegradation. The application of biodegradation for waste water treatment and soil reclamation is called bioremediation.

NBS and Eco-STEPS Inc. ( Eco-logical Sustainability Through Environment Protection Services) employs combination of four technologies i.e. Microbial Degradation, Phyto-remediation, Constructed Wetlands and Up flow Anaerobic Baffled Reactor (ABR) simultaneously for making process more appropriate and efficient degradation of pollutants from wastewater .

The unit operations and processes employed for domestic waste water treatment at Village Chattal are given in table - 2, below:

Table 2. Unit Operations/Processes, Their Functions and Units Used for Domestic Wastewater Treatment

\begin{tabular}{|c|c|c|}
\hline Unit Operations/Processes & Functions & Treatment Devices \\
\hline Screening & $\begin{array}{l}\text { Removal of large floating, suspended and settle able } \\
\text { solids }\end{array}$ & Screens of various description \\
\hline Grit Removal & Removal of inorganic suspended solids solids & Screening Unit \\
\hline Primary Sedimentation & Removal of organic/inorganic settle able solids & Primary sedimentation tank \\
\hline Anaerobic biological growth Processes & $\begin{array}{l}\text { Conversion of organic matter into } \mathrm{CH} 4 \& \mathrm{CO} 2 \text { and } \\
\text { relatively stable organic residue }\end{array}$ & Anaerobic Baffled Reactor (ABR) \\
\hline Anaerobic Stabilization of Organic Sludges & same as above & Same as Above \\
\hline Biological Treatment and Filtration & $\begin{array}{l}\text { Accumulation, conversion of toxic substances and } \\
\text { removal pathogenic strains }\end{array}$ & Sub surface water flow constructed wetland \\
\hline Aerobic Biological Suspended Growth Process & $\begin{array}{l}\text { Conversion of colloidal, dissolved and residual } \\
\text { suspended organic matter into settle able biofloc and } \\
\text { stable in-organics }\end{array}$ & $\begin{array}{l}\text { Free Water Surface Flow Constructed } \\
\text { Wetlands }\end{array}$ \\
\hline Aerobic Biological Attached Growth Process & same as above & Rotating biological Sand Filter \\
\hline
\end{tabular}

\subsubsection{Structural Design Information}

The raw sewage must be treated before it is discharged into the natural system. The extent of treatment required to be given depends upon, not only on the characteristics and quality of the sewage but also upon the source of disposal, its quality and capacity to tolerate the impurities present in the sewage effluents without itself getting potentially polluted. The schematic view of the project site is shown in figure-5 


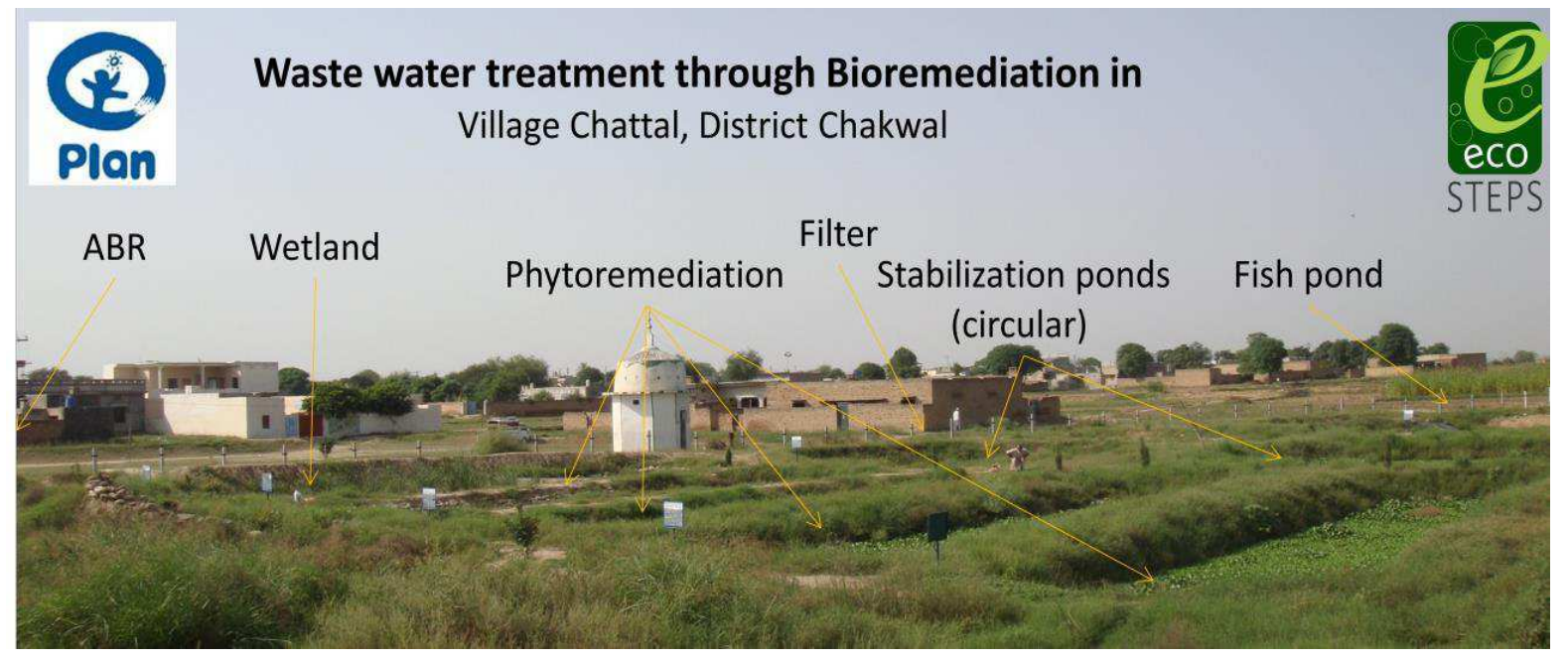

Figure 5. Flow Diagram of Constructed Wetland at Village Chattal

At Village Chattal combination of different biological process were employed for treatment which include anaerobic process achieved through Anaerobic Baffled Reactor (ABR) provide up to $70 \%$ reduction in both
Chemical oxygen demand (COD) \& Biological oxygen demand (BOD). ABR developed as secondary treatment system after primary screening and grit removal. Capacities of various components are shown in table-3, below;

Table 3. Capacities of Different Components employed at Village Chattal

\begin{tabular}{|c|c|c|}
\hline S. No. & Components/Processes Employed & Capacity (US Gallons) \\
\hline 1 & Inlet Drain & 3,291 \\
\hline 3 & Anaerobic Baffled Reactor & 32,201 \\
\hline 4 & Subsurface Horizontal Flow Constructed Wetland & 69,115 \\
\hline 5 & Free Water Surface Flow Constructed Wetland-I & 87,965 \\
\hline 6 & Free Water Surface Flow Constructed Wetland-II & 87,965 \\
\hline 7 & Free Water Surface Flow Constructed Wetland-III & 87,965 \\
\hline 8 & Free Water Surface Flow Constructed Wetland-IV & 87,965 \\
\hline 9 & Free Water Surface Flow Constructed Wetland-V & 128,898 \\
\hline 10 & Free Water Surface Flow Constructed Wetland-VI & 128,898 \\
\hline 11 & Biological Filter & 87,965 \\
\hline \multirow[t]{2}{*}{12} & Treated Water Reservoir \& Rain Water Harvesting Pond & 763,723 \\
\hline & Total & $1,572,626$ \\
\hline
\end{tabular}

For tertiary treatment series of constructed wetlands were established which includes subsurface horizontal flow constructed wetland, free water surface flow constructed wetland which serves as facultative anaerobic, facultative aerobic and aerobic stabilization ponds, where aquatic plants fixed atmospheric oxygen in treated water. Treated water reservoir was established for water storage pond for further reuse in agriculture and fish breeding. Prior to treated water reservoir sand filter was established for removal of leftover microbial flora from waste water. Periodic microbial consortia application is shown in figure-6, below 


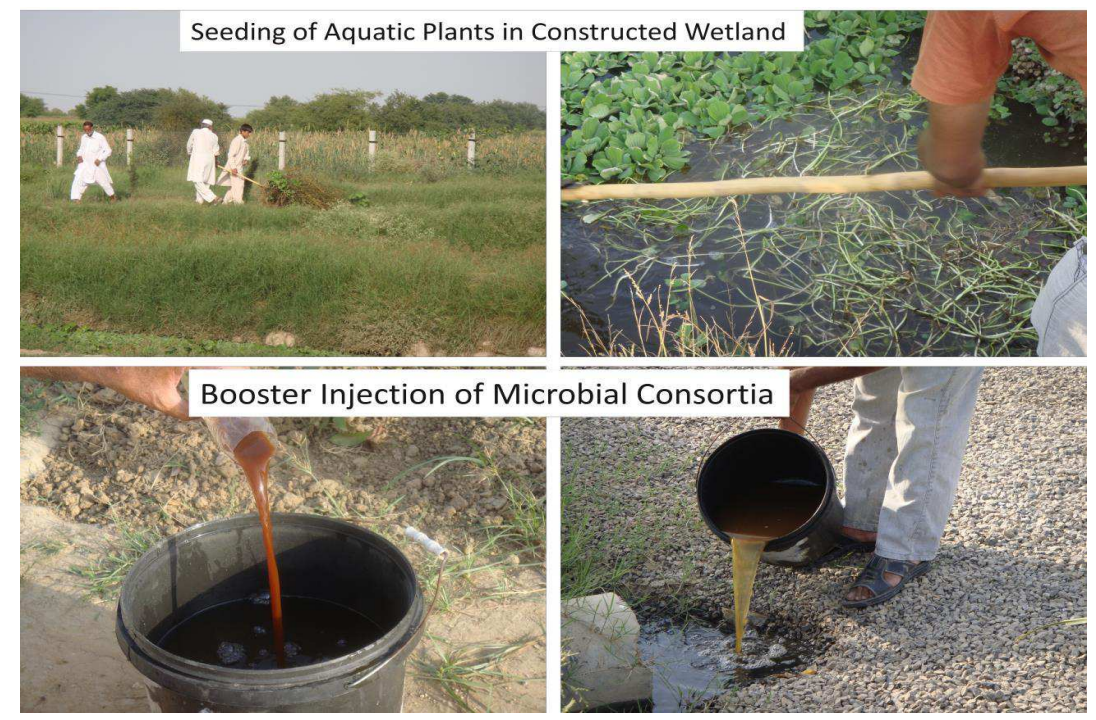

Figure 6. Application of Microbial Consortia \& Seeding of Aquatic Plants in Constructed Wetland

\subsubsection{Water Reservoir as Fish Pond and Composting Pits}

Treated water after anaerobic and aerobic treatment requires storage for harvesting for irrigation purposes so water reservoir was built after constructed wetland and this water reservoir is being used as a fish pond. Fish is a biological indicator for treated water and fish species can only survive with 4-5 mg/L dissolved oxygen (DO).

If there is less DO in treated waste water, then fish can't survive which shows that treated water is not of the desired quality. Fish production also maximize the income generation from the project. Similarly different aquatic plants with higher protein, nitrogen, phosphorus \& potash contents used in bioremediation facility will be harvested regularly and further process for composting. For this purposes composting pits were constructed at project site.

\subsection{Operations and Maintenance}

Bioremediation technology is also very cost effective in its capital and reoccurring costs as compared to mechanical treatment system. It does not involve any kind of chemical and expensive electrical aeration process in meeting water treatment process. Due to these very reasons, local community was mobilized for taking physical ownership of the project. Operation \& maintenance only involves, removal of sludge from bio-digester and grit chamber and removal of debris material from screens. Some services are also required regarding harvesting of aquatic plants on regular basis and overall maintenance of treatment site to be used as recreational site. Requisite capacity building sessions of the project committee was carried out for up-keeping the facility.

\section{Results and Conclusion}

The Hybrid constructed wetlands, embedded with value addition interventions for post project sustainability, was established in the target village (Chattal-Pakistan). Waste water treatment through this facility is fully functional with promising results. Various water quality analysis have been carried out and the results are according to national waste water standards. The physical appearance of treated water can be compared, as shown in figure-7, below

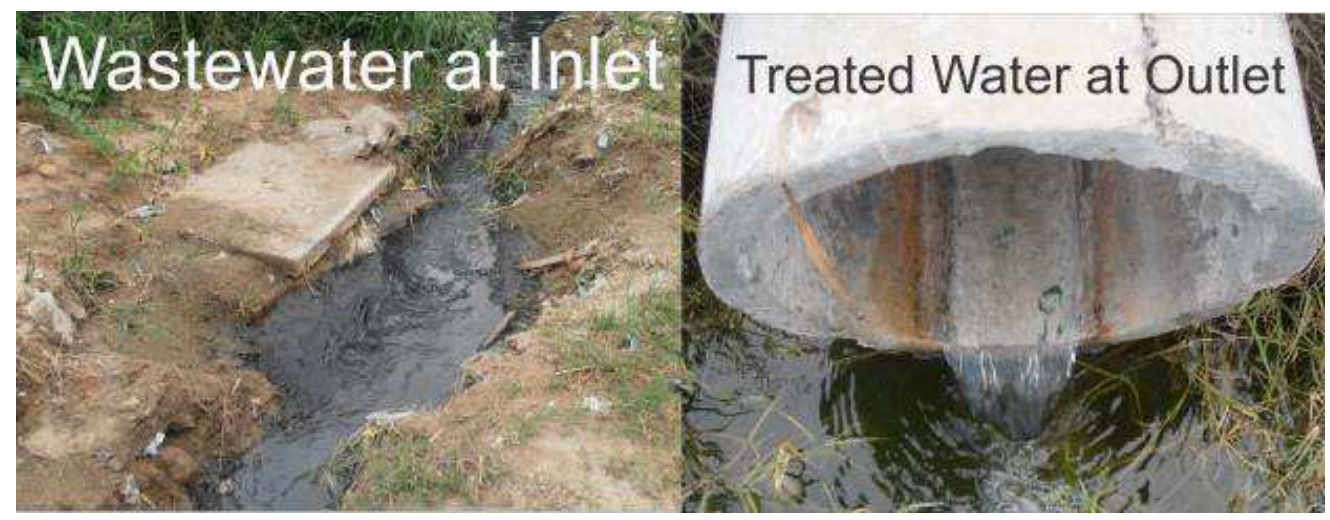

Figure 7. Visual Condition of Water at Inlet \& Outlet of Constructed Wetland Project at Village Chattal

Waste water collected at Inlet point before entering into screening unit and treated water collected at outlet, exit from treated water reservoir was analyzed for Chemical Oxygen Demand (COD) and Biological Oxygen Demand (BOD) 
from PCRWR-Islamabad. Analysis report showed significant reduction of COD \& BOD i.e. $86.1 \%$ \& $91.4 \%$ respectively which are well under permissible limits of Pak-EPA.

Aesthetic value of treated water is remarkably improved after treatment as turbidity reduced from 15 NTU to 2 NTU

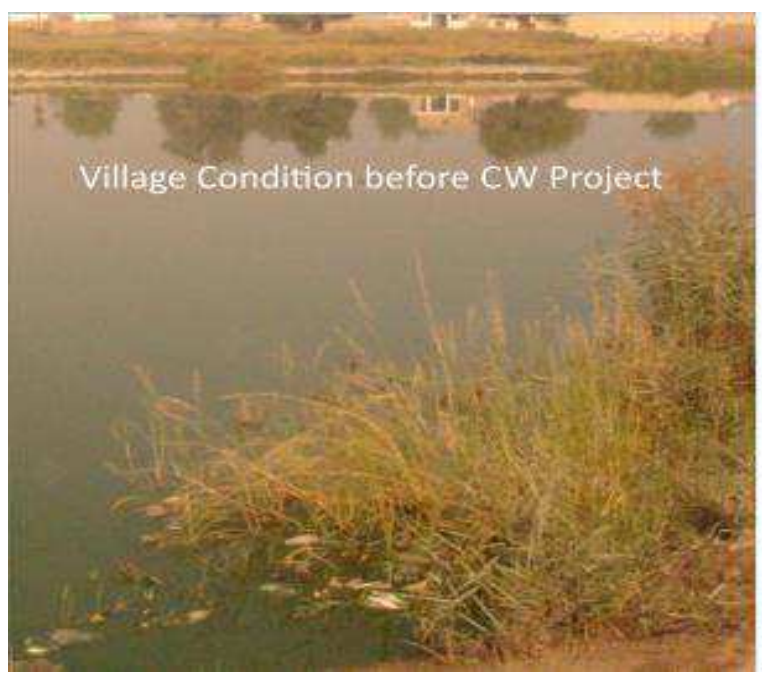

Figure 8. Impact of CW project upon village surrounding areas, with acceptable aesthetic values

\subsection{Measured and Observed Impacts}

\subsubsection{Reduction in Water Related Diseases at Village Chattal, District Chakwal}

The district health representatives carried out detailed survey of village Chattal, District Chakwal, where village sewage is being treated through Hybrid constructed wetlands, as shown in Fig. 5. There is no foul smell at constructed wetland site and whole site look like a water park. The previous waste water pond land has been reclaimed as shown in figure-8, below;

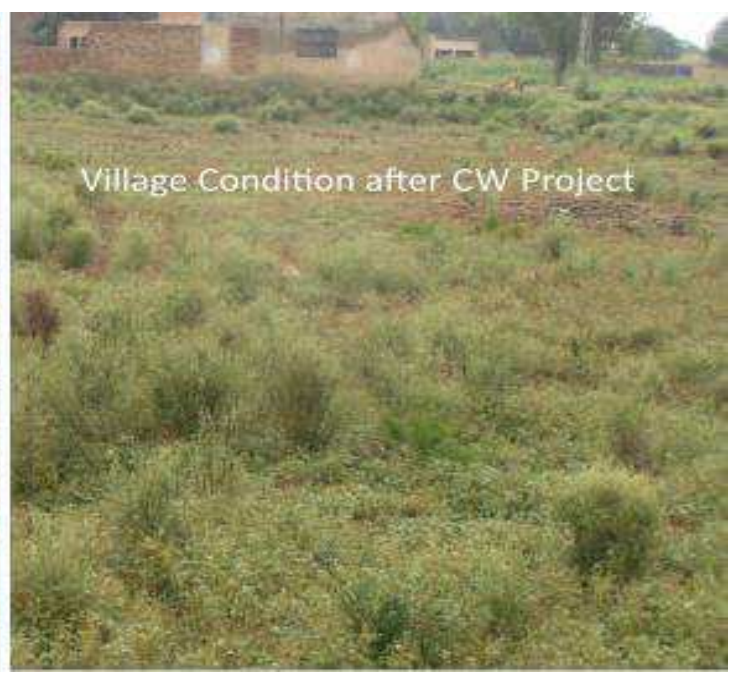

Table 4. Reduction in water related before and after constructed wetlands interventions

\begin{tabular}{lll}
\hline S\#1 & Ratio of Diseases like diarrhea Before the Vet land project & Ratio of Diseases like diarrhea after the Vet land project \\
Analysis & $130-150$ patients per month & $10-11$ patients per month \\
S\#2 & Ratio of Diseases like Hepatitis Before the Vet land project & Ratio of Diseases like Hepatitis after the Vet land project \\
Analysis & 15 Patients from Village & 09 Patients from Village out of 15 \\
\hline
\end{tabular}

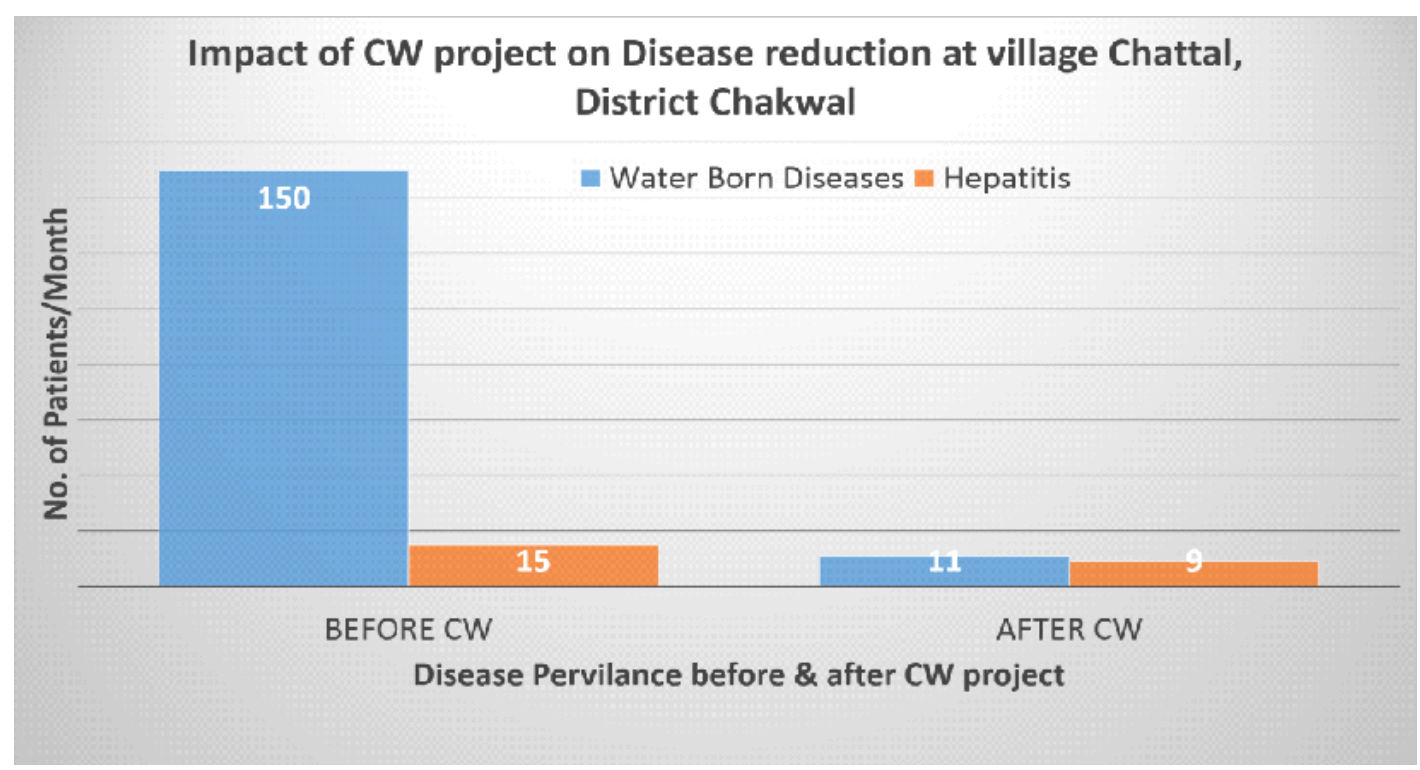

Figure 9. Result of Health Survey carried out District Health representative before and after $C W$ project 
Appreciable reduction in COD \& BOD was noted which indicates the Hybrid constructed wetlands efficiency and

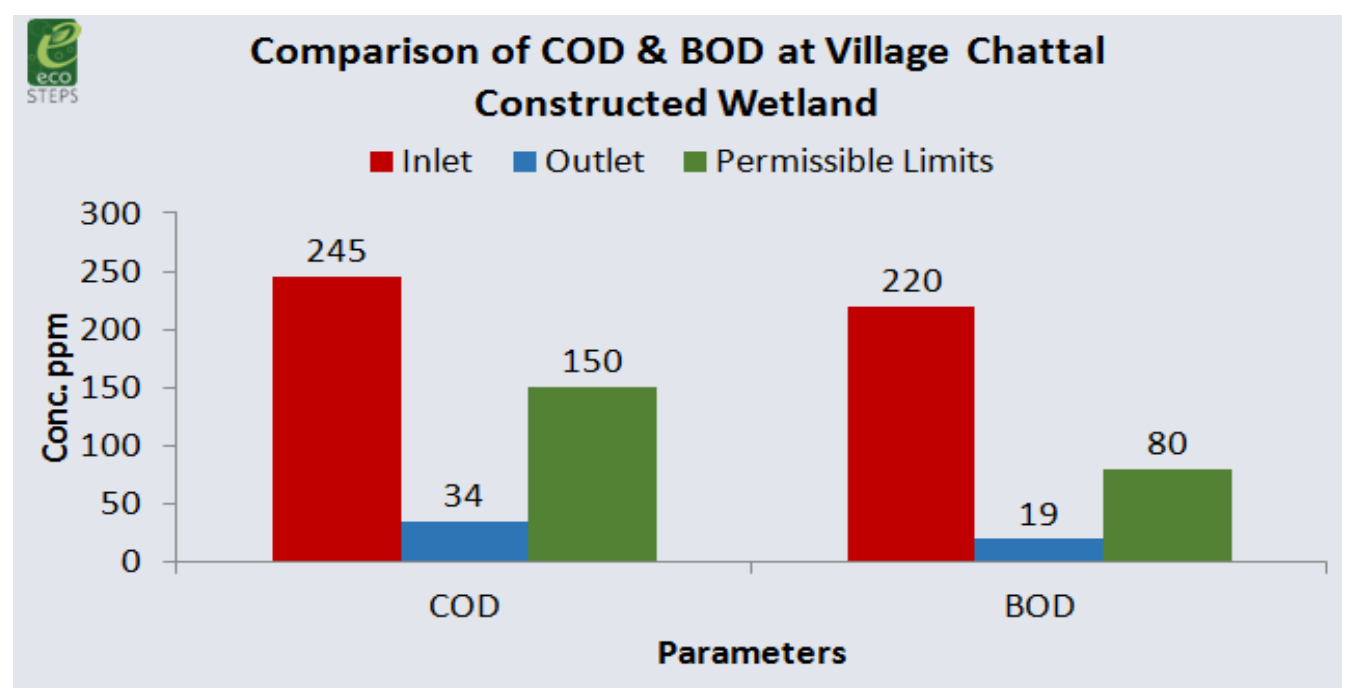

Figure 10. Comparison of $C O D$ and $B O D$ before and after $C W$ project

\subsubsection{Revenue Generation-from Vale Addition Interventions}

Sale of treated water - used for agriculture purposes: The area is arid in nature, therefore, availability of treated waste water to be used in agriculture has motivated the local participation manifolds and in return contributed towards revenue generation.

Fish Breeding in Treated Water Pond: Treated waste water reservoir was further augmented with rain water harvesting also which is being used for fish breeding. Since fish breeding is somewhat a technical field, therefore, wetlands
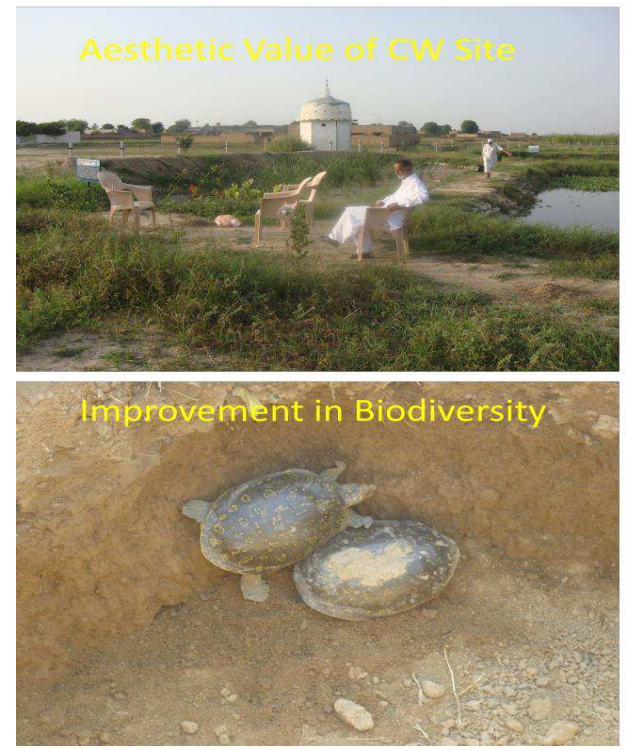

Figure 11. Improved biodiversity conditions -various flora and fauna species

Revenue generation from fruit orchard: Fruit orchard, comprising of various fruit plants species, was established and sizeable revenue is being generated which is being site management committee has outsourced fish breeding activity and now earning approximately Rs 2000 per month.

Harvesting of Aquatic Plants: Regular harvesting of various aquatic plants is being carried out for production of poultry feed, animal fodder and manure, which also generate sizeable revenue for operation \& maintenance of the wetlands system.

Enhanced Bio-Diversity: Due to enabling environment, various flora \& fauna species have been seen in and around wetlands, specially turtles', reptiles and migratory birds etc, as shown in the figure-11, below
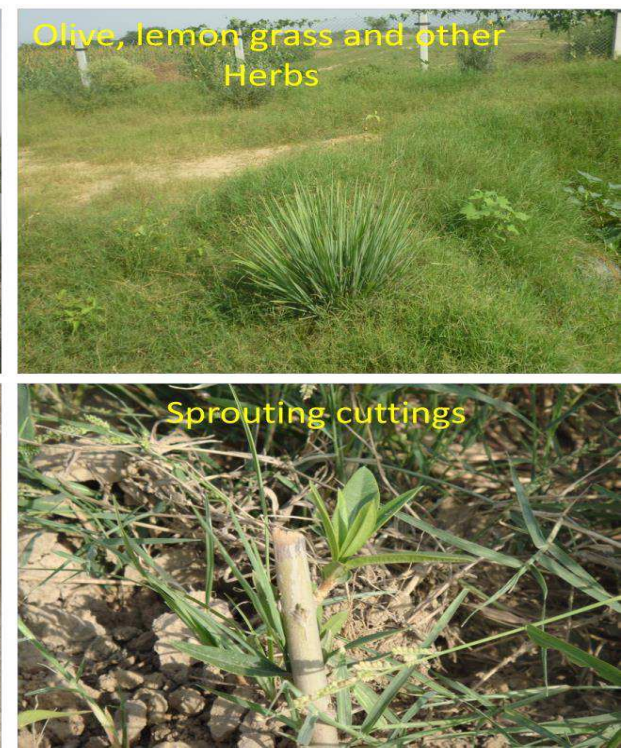

utilized for the further development of the facility. High value fruit species are now being planned, with technical/expert support of national agriculture research 
centre (NARC) for more revenue earnings.

Herbal garden: Various varieties of herbs have been planted, in consultation with renounced pharmaceutical companies which will train the village management committee for efficient sowing of required herbs. Market linkages will be established for profitable disposal of these herbs. Beside this, local community will also be using these products. If properly managed and maintained, this intervention can fetch lot of revenue.

Integrated Farming: This is another main revenue generation intervention which consists of poultry, live stock and vegetable farming, as aquatic plants provide sufficient quantity of feed and compost for these activities.

The wetlands site has further been developed / landscaped which is now being used as a recreational place. Various species of fruit trees have been planted, specially the lemons, which will further contribute to maximize the revenue generation. The lush green constructed wetlands site provides a picnic spot to the inhabitants, as shown in figure-12, below;
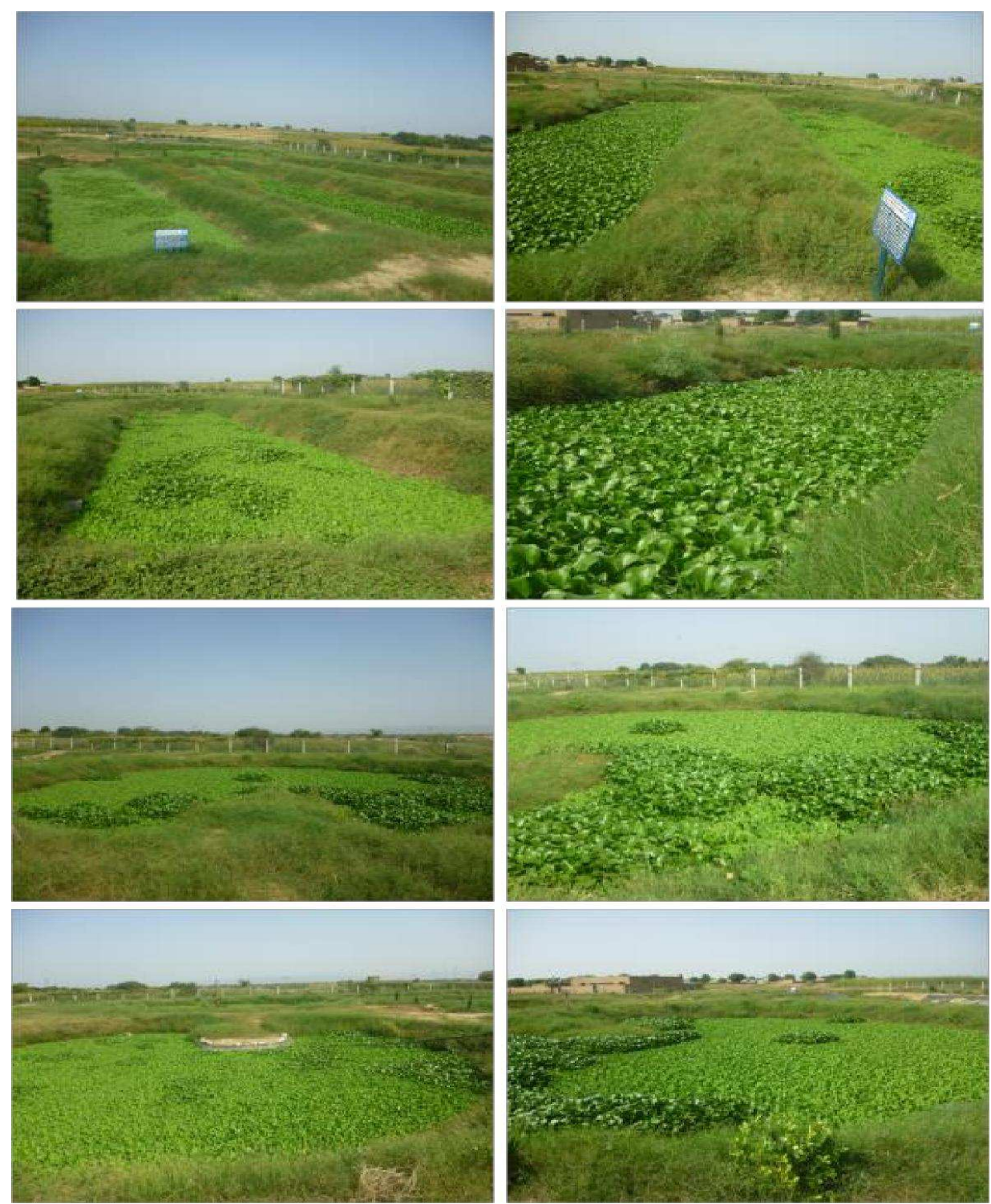

Figure 12. Pictorial View of Site after Completion- a process of bio \& phyto-remediation

\section{Conclusion}

Community based Hybrid constructed wetlands system at village Chattal was made partially operational in December 2012 and became fully functional in May 2013. The waste water (influent and effluents) analysis was promising and according to national standards and guidelines which contributed towards reduction in ground/drinking water contamination. There was tremendous reduction in water related diseases and improvement in health indicators. Since, the project design was embedded with value addition interventions/ livelihood generation, therefore, the local community did not face any financial problem to maintain the facility.

This small / decentralized community based sewage treatment facility is cost effective, environment friendly, financially \& economically viable and sustainable. This 
54Col Islam-ul-Haque and Asim Saleem: Community Based Sewage Treatment through Hybrid Constructed Wetlands System for Improved Heath \& Hygiene and for Enhanced Agriculture Productivity / Livelihood Generation in Rural Water Scarce Environments-Pakistan

model is suitable for the rural communities and can be replicated anywhere in the world.

In addition, various stakeholders (policymakers, water management institutes, health institutes, international development agencies) can use this facility / site as a model and resource centre for demonstration and promotional platform for mainstreaming the decentralized Hybrid constructed wetlands wastewater treatment system, best suited for small and medium sized communities in rural environments. Most of the developing \& under developed countries are confronted with such problems, therefore, this model can be replicated in rural environments of these countries.

\section{Reference}

[1] National Water Quality Monitoring Programme (Fifth Monitoring Report 2005-06) June 2007, Pakistan Council of Research in Water Resources (PCRWR), E - mail: pcrwr@isb.comsats.net.pk Website: www.pcrwr.govt.pk.
[2] Pakistan Strategic Country Environmental Assessment, South Asia Environment and Social Development Unit, Document of the World Bank October, 2006.

[3] Pakistan Economic Survey 2011-12, Ministry of Finance, Government of Pakistan Islamabad.

[4] Pakistan's Water at Risk, Water and Health related issues in Pakistan \& Key Recommendations, Freshwater \& Toxics Programme, WWF - Pakistan, Published 2007 by WWF Pakistan.

[5] PuR Water Purification Reaches Pakistan, United States Agency for International Development USAID Report, http://www.usaid.gov/.

[6] (Krishna Lal Shrestha, 2008). Decentralised waste water management using constructed wetlands in Nepal.

[7] Bhushan Tuladhar, environment public health organization, Decentralised wastewater management using constructed wetlands.

[8] Jan Vymazal, Water 2010, 2, 530-549; doi:10.3390/w2030530- Review, Constructed Wetlands for Wastewater Treatment. 